\title{
UMA ETNOGRAFIA DA EXPANSÃO DO MUNDO DO CRIME NO RIO DE JANEIRO*
}

\section{Carla dos Santos Mattos}

Universidade do Estado do Rio de Janeiro (Uerj), Rio de Janeiro - RJ, Brasil. E-mail: negahcarolcarol@gmail.com

DOI: http//dx.doi.org/10.17666/319110/2016

\section{Introdução}

$1^{\circ}$ de setembro de 2012, 9hs manhä. Tomei um transporte alternativo de Copacabana para participar da Conferência Livre de Direitos Humanos, ${ }^{1}$ no Centro de Artes da Maré. Já bem próximo a meu destino ficamos presos na pista central da avenida Brasil pouco antes de chegar a passarela 9, altura da favela Nova Holanda. Vimos a fumaça dos pneus queimando e pessoas atravessando outras pistas. Logo entendi que se tratava de uma manifestação contra a violência policial. Foi o que imediatamente concluiu uma passageira sentada a meu lado.

A Conferência não aconteceu como planejada. Todos

* Este artigo é uma versâo modificada de capítulos da minha tese de doutorado intitulada Viver nas margens: gênero, crime e regulação de conflitos. Discuti parte do argumento deste texto no GT "Sobre periferias: novos conflitos no espaço público", $38^{\circ}$ Encontro Anual da Anpocs, em 2014.

Artigo recebido em 12/12/2014

Aprovado em 16/02/2016 estavam prestando solidariedade às mães dos jovens executados pelos policiais em mais uma operação de caçada aos traficantes de drogas. Lá também, sendo assessorada por advogados e militantes de direitos humanos, estava uma senhora que teve a casa invadida por policiais que lhe roubaram 1.460 reais. Em determinado momento, foi retirado um grupo de pressão para ir ao 220 Batalhão da Maré apoiar a lider comunitária de uma das instituiçóes organizadoras do evento na conversa com policiais para o esclarecimento

dos fatos. $O$ objetivo era reunir o maior número possivel de relatos para o registro da ocorrência na $21^{a}$ Delegacia de Policia em outro bairro. No caminho, fomos informados de que era importante participar da coleta do relato de moradores vitimas da operação na sede da instituição. Chegando lá, nos acomodamos em uma sala de aula, onde acontece o curso pré-vestibular. Éramos aproximadamente 20 pessoas, entre moradores, ativistas, ativistasmoradores, e logo se iniciou o testemunho de um rapaz sobrevivente. Pouco antes de sair de moto para comprar páo ele disse ter sido alvo dos policiais naquele momento: "eu vi a bala 'estalando' em cima de mim, larguei a moto no chão, vi que eles estavam me 
mirando", "na visão deles preto na rua é bandido". É significativo que não se trata de estar na hora errada e no lugar errado. Nesta lógica qualquer pessoa pode ser vitima de balas perdidas em uma troca de tiros imprevista, o que, obviamente, acontece muito. Mas

não nesse caso

Nova Holanda, Diário de campo.

O desfecho violento da incursão policial, apresentada na epígrafe, não é uma exceção no cotidiano dos moradores da favela Nova Holanda, no Complexo da Maré, Rio de Janeiro. ${ }^{2}$ Ao longo desse dia conversei com alguns moradores que expressaram profunda indignação com a atuação dos policiais, como destaca uma interlocutora:

A polícia sabe muito bem que se entrar de Caveirão de manhã cedo vai ter tiros, eles sabem que os caras [bandidos] estão loucos no fim do plantão... os policiais sabem disso muito bem, sabem que tem a feira armada desde a madrugada [tradicional feira popular da Maré] e que o povo tá na rua, mas os "caras" ainda não foram dormir. Então eles entram sabendo o que vai acontecer, isso eu acho errado, eles [policiais] sabem onde é o burburinho e se entrar vai trocar [tiros] com os caras, por isso eles tinham que evitar. O que ganham com isso? Nada! É guerrinha o que os policiais querem, só isso (Moradora da Nova Holanda, 1/9/2012).

Sua crítica acentua que policiais e traficantes atuam a partir de um mesmo regime de força - a troca de tiros - assim como de interpelações mútuas - a competência de saber "trocar" quando se entra na favela "sabendo o que vai acontecer". Sigo a partir desta crítica. É no mundo vivido da experiência que a moradora argumenta e é desse lugar que policiais e traficantes coproduzem "políticas locais" (Silva, 2014) ${ }^{3}$ (re)traçadas nos contextos das invasões - disputa violenta entre facçóes rivais pelo controle territorial do comércio varejista de drogas nas favelas -, das incursóes dos Caveiróes - carros blindados da Polícia Militar - e das operaçôes de guerra às drogas. Tais dinâmicas são marcadoras de um padrão de governo característico de processos que Gabriel Feltran (2011) conceituou de "expansão do mundo do crime".
Em seu estudo socioetnográfico nas periferias paulistas nos anos 2000, Feltran compreende a "expansão do mundo do crime" a partir de dois processos coexistentes: (i) a emergência do Primeiro Comando da Capital (PCC) como instância normativa nas periferias; e (ii) se opondo a este fenômeno, o resgate da criminalização da pobreza via polarização entre trabalhadores e bandidos (Zaluar, 1985) que restringe a mediação entre a política e as pessoas marginais na cidade. No âmbito da sociabilidade local, o autor identifica o alargamento do léxico-semântico do "crime", responsável por institucionalizar aproximaçôes concretas entre diversos atores sociais opostamente categorizados na visão pública. Nesse contexto, o PCC organiza o universo normativo em disputa no "mundo social" disputas em torno das dinâmicas de integração à sociabilidade no território, à escola, ao trabalho e à religião -, bem como media conflitos por meio da "normatização estrita" da violência e do manejo de moralidades, gramáticas e repertórios compartilhados. Ao explorar a dimensão etnográfica das práticas criminais e de suas relaçôes cotidianas, Feltran indica que o uso da força (letal) e os processos comunicativos compreendem recursos contíguos e, como pretendo apresentar, constituem princípios de interação dicotômicos.

No Rio de Janeiro, a expansão do "marco discursivo do crime" está intimamente ligada à intensificação do confronto armado entre facções rivais e à institucionalização de um exército de combatentes. Com o recrudescimento dos conflitos nos anos de 1990, os "soldados" emergem como figuras indispensáveis na disputa territorial pela venda de drogas no varejo (Mattos, 2014a). Em tal conjuntura, as favelas passam a ser representadas como lócus da ausência do Estado e de "desarticulação" da "vida urbana ordenada" (Machado da Silva, 2008). O debate nesse período se volta à manutenção das rotinas que modificam "a maneira socialmente difundida de conceber e tematizar relações de força implicadas na questão da segurança pública" (Machado da Silva, Leite e Fridman, 2005, p. 2). A "violência urbana" (como representação e experiência cotidiana) ressurge legitimando e contrastando a "linguagem dos direitos" no enquadramento dos conflitos sociais (Machado da Silva, 2015). ${ }^{4}$ 
Comparando três décadas, como moradora e pesquisadora na Maré, descrevo o contexto histórico da emergência da facção e de sua expansão na favela Nova Holanda. Com base no arranjo criminal e suas transformaçóes nos anos de 1990, analiso situaçōes em que a facção vai se transformando em um "quadro da experiência" (Goffman, 2012) sobre a paz e a guerra - além de constituir "redes horizontais de proteção mútua” (Misse, 2003; Barbosa, 2005) e ser uma forma de "autenticar" o direito informal à firma (Grillo, 2013). Pouco depois, nos anos 2000, as "operaçôes policiais", os Caveiróes e as "invasões" (entre facçôes) vão se consolidando como dispositivos responsáveis por expandirem o "mundo do crime".

Examino aqui as manifestaçōes de neurose e humildade 5 com base em narrativas e situaçōes em que a "facção" (frame) articula a força fisicca (armada) e a argumentação como dois princípios de interação. Embora entrelaçados, tais princípios são vivenciados em planos distintos, e suas fronteiras delimitam experiências dicotômicas da vida social. Convém destacar que as conexóes entre esses princípios indicam, por sua vez, os nexos variados entre "força" e "mundo do crime" como padrão de sociabilidade, conforme aponta Luiz Antonio Machado da Silva (2008, 2015). Nas situações em questão, o recrudescimento de saídas violentas é vivenciado lado a lado com as práticas de mediação conhecidas como "desenrolos" (Leite, 2008; Grillo, 2013; Mattos, 2014a). Sumariando os propósitos desta etnografia, poderíamos dizer que tanto as intimidaçóes como as relaçóes entre prestígio, masculinidade e honra (Lopes, 2011; Mattos, 2014a) compóem as performances dos litígios mediados por moradores e traficantes. ${ }^{6}$

Conversar com bandidos, ouvir e ver pessoas sendo mortas em chacinas; encontrar corpos na esquina; viver dias de tiroteio sem poder entrar ou sair de casa; ter o comércio fechado e a reserva de comida acabando na dispensa, certamente, são experiências que atravessam o meu olhar de moradora e pesquisadora na Maré.7 Para que as minhas experiências sejam valorizadas e mais bem compreendidas, estabeleço uma cisão narrativa dividindo o texto em três partes cronológicas. Na primeira parte, "A facçấo como mundo do crime", são as minhas memórias pessoais que organizam a análise das formas de produção de ordem e reivindicação do monopólio da violência local. Narro e comparo dinâmicas criminais que marcaram a minha experiência como moradora de Nova Holanda desde a década de 1980. Nessa reconstrução estabeleço momentos que caracterizam os modos de gestão do crime na favela: da Quadrilha de Jorge Negão, nos anos de 1980, à entrada do Comando Vermelho, em 1994; da disputa entre faç̧ôes rivais, em 1999, à tentativa de Uniäo, em 2011. Marcando temporalidades distintas, situo a neurose e o desenrolo como mecanismos de institucionalização da facção no governo local.

A segunda e terceira partes compreendem situaçôes etnográficas embasadas em uma linguagem muito mais analítica, que caracteriza minha atuação como pesquisadora: em "Neurose e a paz na guerra", discuto o uso da categoria "neurose em conflitos corriqueiros", examinando o ato de "bater neurose" e de evitá-la. Aqui, o núcleo de sentido da neurose, que se contrapóe ao ideal de paz, é questionado e cede lugar ao valor da igualdade como parte do convívio seguro, sobretudo para o universo masculino e juvenil estudado entre os anos de 2011 e 2013 (Mattos, 2014b). Elucidando os recursos disponíveis de resistência ao contexto da igualdade e paz entre os homens, por fim, na terceira e última parte, "Humildade, paz e igualdade", abordo um caso particular de conflito conjugal, explorando os limites e as possibilidade do agenciamento de mulheres na mediação de conflitos que envolvem litígio fundiário e violência doméstica.

\section{A facção como "mundo do crime"}

\section{Favela Nova Holanda, 1985}

Nessa época, morávamos em barracos de madeira. Saí à noite para visitar um tio numa rua próxima, onde os barracos tinham dois andares - modalidade de construção conhecida como Duplex. No caminho, presenciei uma cena que até então me era desconhecida: um homem negro joga uma pistola no canto da rua e corre. Em seguida, sozinho, um policial militar caminha a passos largos, apresentando sinais de cansaço. Com a arma em 
punho apontada na direção do homem em fuga, o policial "sabia" o alvo. Entrei no Duplex do meu tio e ouvimos alguns tiros. Coisa pouca, não teve revide. Curiosa, perguntei: "Tio, por que existe bandido?" Nunca me esqueci de sua resposta: "Existe pras pessoas não pensarem que podem chegar do nada e dar facada um no outro... aqui tem muita rixa entre famílias, se não fosse o bandido, ia ser muita morte aqui".

Além de não poder ameaçar e matar, nesse dia também soube que não era permitido roubar dentro da favela. A despeito desse controle, todavia, eram recorrentes as brigas entre homens "valentes", jovens e adultos, entre mulheres e integrantes de famílias rivais. Alguns "malandros" até andavam com uma arma "38" na cintura, mesmo sem serem "bandidos". Nada disso interferia nos negócios do incipiente tráfico de drogas chefiado por Jorge Negão e seus comparsas na década de 1980. Assim como outros "donos", Jorge Negão matava ladróes, "xisnoves" (delatores) e intervia em conflitos interpessoais apenas se a vítima o procurasse por ameaça de morte ou roubo. Uma vez que o envolvesse no caso, diziam, não era possível voltar atrás. A retirada de uma queixa costumava ser tomada como quebra de confiança pessoal e, dependendo de seu humor, Jorge Negão poderia até tornar o réu sua vítima fatal. Essa era a imagem de bandido mau que circulava na época e que Jorge Negão desempenhava em alguns rituais cruéis, como a crucificação de quatro irmãos. ${ }^{8}$ Jorge matava em um dia reservado: quando virava o boné para trás! A personificação do ordenamento da força segue um controle social muito estrito, ritualizada na persona que garante a paz e a segurança dos moradores. Restrita, a sua prática de apropriação da força era personalizada. Ainda que fazer a segurança da comunidade fosse considerado legítimo, Jorge Negão não disputava a legitimidade de outra ordem social. Mesmo quando sua quadrilha disputou o território com outra, a dos Irmãos Metralha, a paz surgiu como uma demanda da Associação de Moradores e de mobilizaçóes ligadas à Igreja Católica, ao grupo de mulheres existente na época, às agentes comunitárias e ao bloco carnavalesco Mataram o Meu Gato. Foi a partir da reinvindicação desses atores que a paz fora negociada conforme narra Eliana Souza:
A mobilização comunitária influenciou o processo que ocorreu. [...] Os dois grupos, o dos Irmãos Metralha e o de Jorge Negão, começaram a tomar iniciativas para encerrar os conflitos e permitir que os moradores de um lado transitassem sem medo para o outro. Eles mantiveram sua autonomia, mas estabeleceram a trégua solicitada pela população [...]. Como muitos moradores e vários integrantes das quadrilhas não acreditavam nessa possibilidade, foi realizada uma demonstração pública dos dois lados, ritualística, para a formalização do combinado. Assim, em um determinado dia e hora definidos pelos chefes, os dois grupos vieram caminhando dos seus lados, com todas as suas armas na mão. $\mathrm{O}$ momento, recordo-me ainda hoje, era de temor, de tensão, de forte expectativa. Eles, sempre se olhando, se dirigiam para defronte do posto policial comunitário - os policiais de plantão estavam dentro do imóvel, mas não efetivaram nenhuma ação, pois sabiam o que estava previsto para ocorrer. No mesmo momento, então, os integrantes dos dois lados jogaram suas armas no chão. A atitude, assistida por muitos moradores, inclusive por mim e os policiais de plantão naquele dia, significou um novo momento para a Nova Holanda. Desde então, a guerra acabou e a paz reinou entre as quadrilhas criminosas da Maré por muitos anos. Ela foi quebrada apenas a partir de meados da década de 1990, em função dos novos arranjos entre os grupos criminosos armados cariocas" (Silva, 2010, pp. 102-103).

\section{Comando Vermelho, Paz, Justiça e Liberdade Rogério Lemgruber (CVPJLRL), 1994}

Em 1985, quando me mudei para a Nova Holanda não havia qualquer tipo de fronteira entre quadrilhas. Após a morte de Jorge Negão, no início da década de 1990, o seu sucessor, Gigante, seguiu a prática de matança como ritual de demonstração de força. Entretanto, ele se deparou com uma nova realidade na organizaçáo do varejo de drogas no Rio de Janeiro com o fortalecimento das facçóes criminosas. Em 1994, a quadrilha deixou de ser neutra, como diziam, e articulou-se ao Comando 
Vermelho. Foi um momento de grande circulação de armamento pesado e receptação de mercadorias roubadas (cordōes e relógios de ouro, anéis de brilhante, roupas, perfumes etc.) e, principalmente, carros e motos. Nesse momento, os ladróes passaram a trabalhar exclusivamente para os traficantes que lhes emprestavam armas.

A quadrilha que atuava na Baixa do Sapateiro, favela vizinha, optou pelo Terceiro Comando. Entre 1994 e 1997, o conflito foi evitado porque o braço direito do "dono" do tráfico da Nova Holanda era afilhado do líder da facção rival. A polícia militar só entrava para pegar o "arrêgo" (propina). Foi um período mais calmo, de muita negociação no jogo de "mercadorias políticas" (Misse, 2003), mas que, em um determinado momento, ficou dificultado pelas frequentes incursões policiais para sequestrar traficantes. ${ }^{9} \mathrm{O}$ valor exorbitante que os policias exigiam para o resgate de um traficante $o$ transformou na mercadoria mais valiosa desse mercado de extorsōes. Quando isso acontecia, todos os comerciantes eram obrigados a contribuir.

A quadrilha do Gigante promoveu uma chacina no dia 24 de setembro de 1993, executando oito pessoas que estavam na "lista" para morrer. O que se dizia era que alguns tinham dado "derrame na boca", ${ }^{10} \mathrm{e}$ a maioria porque tinha relaçóes de amizade com policiais. O cerco que os policiais militares faziam com os sequestros e as práticas de extermínio na favela, como a que ocorrera em Vigário Geral há um mês da chacina em questão, fora determinante para a composição da "lista" e das mortes. A despeito desse episódio sangrento, não me lembro de tiroteios e impedimentos na circulaçáo em diferentes favelas que integram o Complexo da Maré; aliás, era uma época em que transitávamos sem preocupaçóes.

O enunciado fação já aparecia em pichaçōes nos muros e em fuzis com as siglas CVPJLRL (Comando Vermelho, Paz, Justiça e Liberdade, Rogério Lemgruber $\left.{ }^{11}\right)$; aos poucos, a nomenclatura foi se agigantando com a inclusão das letras iniciais dos gerentes de bocas de fumo locais. Desse léxico, até aqui, não se desprendia nenhuma fronteira física que extrapolasse a mera identificação das redes de proteção e alianças entre quadrilhas e lideranças do tráfico. Tal como na década anterior, matavam-se delatores, ladróes da localidade e estupradores.
A intervenção de bandidos em casos de ameaça também seguia a lógica personalista da qual pude me beneficiar num caso em que meu padrasto se envolveu em uma pequena batida de veículos entre duas ruas movimentadas. $\mathrm{Na}$ ocasião, o outro motorista pediu desculpas e seguiu. À noite, ele apareceu na porta da minha casa com um rapaz que se dizia "envolvido na boca" 12 e cobrava pelo reparo da parte amassada do veículo. Meu padrasto recusou-se, e na discussão se defendeu a partir, em suas palavras, "do ponto de vista da realizaçâo de uma perícia”. Fazer referência à perícia, ou seja, ao julgamento legal foi o argumento que o rapaz usou para tentar se favorecer na contenda: "aqui náo tem perícia, a perícia é nós, vamos partir pras cabeças!", disse, se retirando após a ameaça. Perplexos, eu, minha mãe e meu padrasto seguimos na madrugada tentando achar o Peruano, gerente da boca situada à rua em que morávamos. Na mesma noite, quando o vimos, ele já sabia do ocorrido. O rapaz o encontrou antes de nós. Imediatamente, o Peruano nos acalmou: "vão tranquilos que nem deixei o cara explicar o caso, somente perguntei de quem estava falando. Quando ele disse que eram vocês, eu mandei esquecer o assunto e cada um ficar com o seu prejuízo".

Nesse caso, o recurso para a resolução de conflitos da estima pessoal foi dispensar argumentos e a necessidade de mediaçáo. O "fortalecimento" (proteção) de "seus queridos" estava acima de qualquer argumento. Segundo me contou, Peruano fazia a mediaçãoo entre as facções rivais para evitar a violência "entre as comunidades". Depois de sua morte, em 1997, a rivalidade só fez aumentar e, em 1999, explodiu a guerra entre facções na Nova Holanda.

\section{"A favela está em guerra", 1999}

Com a favela em guerra, ficamos sob o impacto das tentativas de "invasão"13 e tiroteios diários entre duas facçôes criminais Comando Vermelho versus Terceiro Comando. ${ }^{14} \mathrm{~A}$ prática criminal desse período (1999-2002) consistiu no uso sistemático da força armada contra o alemão (facção rival). Foi uma época marcada pela movimentação intensa de bandidos apontando fuzis para a "divisa" (fronteira territorial entre duas facçóes) e dando tiros a esmo 
para o outro lado. Nesse cenário, obtêm vantagem e emergem como personagens importantes os "bandidos neuróticos" que, seguindo o idioma psicológico, eram mais perturbados ou nervosos. Diferentemente do "homem mau", a ação do "bandido neurótico" foi peça-chave na realização e composição das "missóes" 15 do Comando Vermelho. Aliado a essa rede, tais bandidos atuavam ainda em diversas frentes de batalhas. À época, considerávamos que a sua performance bélica, de temperamento instável, negava o trato cordial com as pessoas.

Mesmo que a tomada do território não tenha se concretizado em nenhum dos lados, o espectro da ameaça de invasão ditava o ritmo que passou a prevalecer. Ancorada em situaçôes, eventos violentos, sensaçóes e expectativas, a neurose, bem como o processo comunicativo dessas experiências, deslocava as ações da persona para o emblema facção, tornando-a um ponto de observação a partir do qual se tentou estabelecer um conjunto de tipificaçôes legíveis e habituais. "Fiquei com neurose, bateu neurose, o ritmo tá neurótico, maior neurose", eram locuções correntes desse período que não se enquadravam em uma única definiçáo. Várias sensaçôes poderiam dar sentido à neurose: adrenalina/ excitação, medo, ansiedade, estado de alerta e frenesi na vizinhança. A neurose também estava associada aos boatos produzidos por pessoas que se falavam ao telefone no intuito de saber o que estava acontecendo nas ruas, buscando mais informaçóes, principalmente quando não era possível entrar na favela. Neste caso, a pessoa ficava por horas aguardando na avenida Brasil uma avaliaçáo do melhor "clima" para uma volta segura.

\section{A facção, o $22^{\circ}$ Batalhão da PM e o Caveirão}

"Oficial planejou entregar jovens a traficantes rivais, diz polícia do Rio”

A polícia civil do Rio afirma que um tenente teria arquitetado a entrega dos três jovens do morro da Providência (região central) aos traficantes do morro da Mineira, no sábado (14). O oficial está entre os 11 militares presos apontados como os responsáveis pelo crime. A favela da Mineira é controlada pela facção criminosa ADA (Amigos dos Amigos), rival do CV (Comando Vermelho) que controla o morro da Providência (Folha de S.Paulo, "Cotidiano", 16/6/2008). ${ }^{16}$

A reportagem noticia um caso emblemático que demostra como um modus operandi de violência policial legitima a rivalidade entre facçôes. Poderíamos afirmar que o acontecimento, conhecido como "O Caso Providência" indica uma forma de apropriação policial da neurose, usando-a como modalidade de gestão das mortes de jovens em favelas cariocas. É no interior dessa lógica que compreendo a instalação do $22^{\circ}$ Batalhão da Polícia Militar e o uso do Caveirão, em 2003, na Maré. O Batalhão foi implantado no mesmo ano em que os carros blindados da PM - chamados de "blindados" ou "Caveiróes" - iniciaram suas incursôes nas favelas cariocas. A expectativa era que o Batalhão poderia ser uma esperança de pacificação dos conflitos entre facções no local e, para isso, esperava-se que o quartel fosse instalado na "divisa". Não foi o que aconteceu. Não tenho informações detalhadas sobre a decisão contrária à opinião dos moradores, mas essa implantaçáo se deu nos limites entre a Nova Holanda e a via expressa Linha Vermelha. "Por que não na divisa? Um absurdo", foram reprovaçóes imediatas que ouvi dos meus vizinhos e amigos e da qual compartilhei com muita indignação.

Sabíamos, sobretudo, que a segurança que se evidenciava com a escolha do ponto de instalação do Batalhão era voltada para os motoristas que passavam na referida via. No dia de sua inauguração, helicópteros jogaram panfletos que anunciavam a paz e incentivavam os moradores a denunciar os traficantes da área. Uma banda desfilou em ruas desertas e as crianças se divertiram marchando junto. E, assim, o Batalhão virou piada. Os meninos na esquina caçoavam e, entre risadas e insultos, gritavam "olha o circo". "Virado de costas" para a Maré, costumava-se dizer, o único acesso direto à favela servia de garagem dos Caveiróes.

A cada trânsito dos "blindados" saindo ou entrando no Batalhão acontecia um intenso tiroteio com os traficantes. A não instalação do Batalhão em zonas de conflito armado fazia da pretensa paz um projeto contrário à demanda de manutenção da 
ordem. No contexto de prática policial, em cenário conflagrado de conflito entre facçóes, a percepçáo que tínhamos era que a "paz" na Maré, concretamente, só seria possível se todas as áreas fossem dominadas por uma única facção. Neste cenário de incertezas, o Caveirão representa a política estatal que se faz nas fronteiras entre favela e asfalto, entre a Nova Holanda e a Linha Vermelha. O cenário explicita o papel das forças atuantes de segurança pública. A cada tiroteio, uma inflexão no mosaico de interesses no "jogo de mercadorias políticas" (Misse, 2003).

\section{"Viva e deixe viver", 2011}

Como vimos, a prática guerreira do período que localizo entre 1999 e 2002, sob a hegemonia dos neuróticos, caracterizou o estilo de controle do tráfico até Andrezinho Moral assumir o comando do tráfico. Moral era parente próximo do ex-chefe da Nova Holanda e morador do Complexo do Alemáo. Para comandar de fora, Moral dividiu o poder com os gerentes das bocas de fumo, criando um grupo de patróes formado pelo "dono" da favela e seus "gerentes" encarregados, entre outras coisas, de mediar conflitos nos desenrolos. O exercício deste patronato suplanta o poder dos soldados de guerra, restringindo-os à força violenta de revide aos Caveirôes.

Andrezinho Moral, ou apenas Moral, organizou a "guerra" preferindo evitar as imprevisíveis e abruptas quebras de rotina. Ao priorizar a rotina pacífica e os laços de confiança de seus patróes amigos, Moral ficou conhecido como defensor do lema: "viva e deixe viver".

Morto em 2009 pela polícia no Morro da Chatuba, Complexo do Alemáo, Moral parece ter deixado o seu legado na gestão compartilhada. Até a finalização da pesquisa, aconteceram algumas tentativas de invasão, mas até esses confrontos começaram a ser mais controlados, percebidos como indesejáveis. A "troca [de tiros] com os alemão" concentra-se em determinados períodos e, quando isso ocorre, a "comunidade" recebe um informe, sempre repassado por boatos. Nesse momento, os imprevistos e tiros a esmo que acontecem cotidianamente, característicos do antigo processo, passaram a ser prática expressamente proibida. Tudo pre- cisa ser "desenrolado" a ponto de se tornar factível a recente tentativa de uniäo entre faç̧óes em abril de 2011, exemplo paradigmático do uso do desenrolo como prática de gestáo política da ordem criminal, mas ainda muito questionada entre traficantes.

\section{Neurose e a paz na guerra}

09 e 10.04.2011 - (sábado e domingo)

Eu estava na Região Serrana quando a minha amiga me ligou, no sábado, para me avisar que as tentativas de invasão continuam [invasões que pareciam iniciadas após o tiroteio no samba]. O dia foi de muitos tiros. Resolvi não voltar. No domingo pela manhã retornei a ligação para saber como andava o clima e soube que o baile Funk acabou com outra tentativa de invasão. $\mathrm{O}$ tiroteio continuava e a favela estava deserta. No final da tarde, minha amiga ligou eufórica dizendo que logo após um intenso tiroteio acontecera algo inédito: "eles fizeram a paz". Guerra e paz no mesmo dia. $\mathrm{O}$ inusitado era saber os motivos, mas ela não sabia; o que se podia ver era uma intensa comemoração nas ruas: buzinaços, burburinhos, aglomeraçôes de pessoas nas ruas, muitas motos transitando.

\section{1 - 13.04.2011 (Segunda a quarta)}

Falava-se na organização de um baile da paz. $\mathrm{O}$ filho de minha amiga, 15 anos, disse ter ido até o outro lado [da "divisa"] para cumprimentar os amigos de escola que moram no território "dos alemão". De fato, onde se ia sempre tinha alguém fazendo referência à livre circulação na Maré "agora pode, acabou a guerra". Presenciei muitas brincadeiras "vai lá você, eu não". Sempre quando encontrava um conhecido, a inevitável e curiosa pergunta vinha à tona: "tá sabendo da união?”. Colhi três interpretações diferentes sobre os motivos da paz: (i) afirmação da resistência contra a UPP e milícias; (ii) invisibilização do crime e violência local - o fim dos tiroteios evitaria o efeito midiático da entrada da UPP; (iii) estratégias de infiltração entre as facções - o chamado "golpe de estado". 
A interpretação do "golpe de estado" foi ganhando força na terça-feira. Fui almoçar na pensão localizada na rua Principal. Passei próxima ao que parecia um debate sobre a nova situação. Não dava para ouvir, mas via vários homens exaltados falando como se tivessem revoltados com alguma coisa. Não tinha ninguém armado. Um novo rumor se espalhava.

Dizia-se que, com a paz, muitos moradores envolvidos estavam circulando na Nova Holanda ( $\mathrm{NH}$ ) para reconhecer território, se infiltrar e dar o golpe.

\subsubsection{1 (Quinta-feira)}

2:54 da madrugada: acordo com o tiroteio, penso se é seguro ficar no quarto e vou para a sala. Motos em alta velocidade e homens gritando muito. Não existia mais a união. A facção rival tenta entrar, as armas dos de lá são mais potentes. Às 4:39 ouço o barulho de fogos indicando a entrada da polícia. Os tiros não cessam até que explode uma granada. Acabou. Fui dormir.

No dia seguinte, tinha aula na Uerj. A favela ficou esvaziada, vi mães desesperadas indo buscar os filhos na escola. O comércio, escolas, postos de saúde começaram a fechar. A minha vizinha chegou com a filha, chorosa e pálida, elas viram um caminhão de armamentos que estavam sendo distribuídos entre os bandidos da NH. Não sabia se saía da favela naquele momento. Esperei. Vi muitas crianças voltando da escola. Pensei que se não saísse naquele momento, poderia ficar presa em casa sem comida. Consegui sair. No ponto de ônibus encontrei uma conhecida que, igualmente, não queria ficar presa dentro de casa e resolveu sair antes que acontecesse um novo confronto. Outra vizinha tentava fazer o caminho inverso. $\mathrm{O}$ posto de saúde em que trabalhava fechou. Ela estava na avenida Brasil tomando coragem para entrar e voltar pra casa.

Os fragmentos descrevem as tentativas de união entre facçóes na Maré e a emergência do desenrolo operado nas fronteiras internas ao mundo do crime. Fica evidente que o entrelaçamento da guerra e da paz produziu a neurose como incerteza e especulação cotidianas que inviabilizaram o trânsito entre estas fronteiras indefinidas. A neurose como paz na guerra permanece sendo uma ameaça à produção pacificada da ordem. A evitação e a institucionalização da neurose como visão dicotômica entre a guerra e a paz são reveladoras no relato etnográfico que descrevo a seguir:

Era madrugada, num bar de esquina, uma mulher começa a berrar. Com a fala enrolada, não havia dúvidas quanto à sua embriaguez. Olhei da janela e ela era a única freguesa. Do outro lado da rua um grupo de garotos caçoavam dela: "cachaceira" "favelada" e "mulher feia". Ela retrucava: "estou bebendo com o meu dinheiro, sou trabalhadora, não dependo de ninguém”. E eles zombavam cada vez mais, sempre repetindo: "cachaceira", "favelada", "mulher feia". Então a mulher quis dar um fim ao escárnio: "eu bebo sim, sou feia e favelada sim, mas eu sou CV! E vocês? Vocês parados aí na esquina? É tudo Xisnove!” E ela repetiu incansável Xisnove, Xisnove, Xisnove! Os garotos saíram imediatamente (Nova Holanda, Diário de Campo, 2010).

Nesse outro trecho uma inversão na correção de forças aparece compondo o cenário da neurose. A divisão espacial de gênero informa a atuação dos rapazes que estigmatizam a mulher por seu comportamento de beber sozinha no bar. A reprovação sexista de sua embriaguez é consonante com a reserva da conduta pública aos homens. Primeiro, a mulher se defende e ressalta sua independência financeira e moral de trabalhadora; em seguida, prefere tencionar a situação tecendo uma trama na qual os rapazes são trazidos à cena e expostos a um típico enredo criminal. A fonte de poder reside no uso estratégico da acusação de "xisnove" que, neste contexto, realiza a contaminação moral que a mencionada categoria supostamente faz fluir. Eis a ação eficaz que proporciona a inversão: fazer uma acusação grave próxima a uma boca de fumo. No mínimo, o barraco (escândalo) poderia chamar a atenção e todos teriam de "ir pra desenrolo na boca". Especificamente, a acusação de "xisnove" foi eficaz na medida em que, ao mesmo tempo, deslocou o mérito da discussão, desacreditando os oponentes.

A condição de "xisnove" mina posiçóes fundamentais para a entrada no desenrolo em condição fa- 
vorável. Na prática, os garotos efetivamente estavam "xisnoveando" a senhora que, mesmo tendo condiçóes de pagar a conta, estava em conduta passível de reprovação moral e social por familiares, amigos e vizinhos. Talvez a mulher, por estar embriagada, não ganhasse credibilidade, mas vai saber? Um conflito que poderia se agudizar foi debelado pela ação da senhora com a decorrente evitação de uma situação arriscada por parte dos garotos. Trazer a facçâo para a contenda é declarar guerra, tornando-a um meio de alcançar a paz entre pessoas "iguais".

Dizer que a mulher "bateu neurose" com os garotos seria uma interpretaçáo muito comum em casos como esse. O recuo dos rapazes corrobora outra reivindicação de pacificação criminal construída por meio de expectativas, interaçóes e circuitos pacificados (Mattos, 2012). São nesses circuitos, identificados com uma facção, que muitos jovens moradores de favelas vão circular seja em favelas "conhecidas", seja em praias como o Arpoador, seja em Ipanema, na Zona Sul. Na guerra espera-se a paz; na paz evita-se a guerra. Porque estavam integrados ao convívio seguro, os rapazes evitaram a "guerra" da mulher. O desmonte da cena sexista não ocorreu nos termos de uma crítica à desigualdade de gênero. A acusação de desordem e desrespeito é o pano de fundo que permite plausibilidade à fala da mulher compartilhada pelos rapazes, sem constituir, no entanto, uma sociabilidade hegemônica. Nesse caso, o enunciado facção "expande" o crime como campo argumentativo na disputa por legitimidade local.

A ameaça pela força confunde-se com a expectativa juvenil de pacificação masculina que organiza as interaçôes entre os "bondes parados na esquina" (Mattos, 2014b). Nos encontros e conversas com integrantes de diferentes grupos, pude perceber que, para eles, a interação face a face com traficantes armados náo implica relações instrumentais de força. Isso não quer dizer, entretanto, que tal imposição armada não tenha efeito coercitivo. Em situações conflitivas e agressóes pessoais - em brigas "por causa de mulher e futebol" -, costuma-se recorrer ao fundamento do Comando Vermelho no "desenrolo" com bandidos. Os argumentos mobilizados nessas conversas são apropriações de valores legítimos de paz, justiça, liberdade e, sobretudo, igualdade. Antes de tudo, preza-se pela amizade. ${ }^{17}$ Nesses conflitos, mesmo o rapaz armado não pode se prevalecer diante dos outros. Todos são "sujeito homem". Além disso, são "crias" - ou seja, nascidos e criados na favela - e merecem consideração, não por sua força física e disposição pela luta, mas por sua moral. Desse modo, mesmo nos limites físicos e simbólicos da facção, que são restritos, existe a possibilidade de viver em paz. Nesse sentido, a pacificação criminal disputa e expande valores legitimados para segmentos de moradores de favelas. Integrados, os jovens compartilham laços de reciprocidade associados ao ordenamento do crime (Lyra, 2013). ${ }^{18}$

Intimamente associada aos "desenrolos", a humildade aparece como um dos dispositivos morais do fundamento responsável por equalizar o convívio entre amigos segundo a prerrogativa "de não querer ser mais do que ninguém”. Na prática, a humildade implica um parâmetro de justiça de "não julgar o próximo", o que, por sua vez, legitima outro mandamento: "cada um com o seu cada um". Entre os bondes que misturam ladrôes, maconheiros, atividade de "radinho do tráfico", "fogueteiro" e os que não são ligados ao crime -chamados de "normais" -, "não julgar o próximo" torna-se um valor dos mais significativos que justifica a mistura de perfis. Dessa prerrogativa, o que vale é a pessoa, e não o que ela faz ou possui (Mattos, 2014b).

Assim, as moralidades abordadas conformam um regime pacífico compartilhado da vida "sem neurose" que, não obstante, segue sempre à espreita

\section{Humildade, paz e igualdade ${ }^{19}$}

Michele $^{20}, 35$ anos, é nascida e criada na favela onde sofreu os episódios de agressão física e psicológica de seu ex-companheiro. Mesmo consciente de seus direitos e decidida a acionar a Lei Maria da Penha, ela se viu impossibilitada de tomar tal providência. Por morar em favela, Michele recorreu ao "desenrolo". A Lei Maria da Penha foi usada como recurso discursivo que remete à linguagem dos direitos, no entanto, no contexto do "desenrolo", sua identificação como mulher fiel foi a condição para se fazer o uso bem-sucedido dos termos da lei estatal. ${ }^{21}$ 
Após três anos de casamento, brigas e agressões, Michele decidiu se separar de Marcelo. Ele a espancou, e Michele foi hospitalizada. Considerando a possibilidade de homicídio, ela pediu a separação. Marcelo se recusou a sair de casa e continuou a pressioná-la. Ao ganhar alta do hospital, voltou para casa e pensou em acionar a Lei Maria da Penha desejando a punição de seu agressor. Michele náo sabia ao certo quais eram as consequências da aplicação da Lei, nem as suas medidas de proteção e punição, mas sabia que se requereria uma intervenção policial - sempre indesejável - em território onde há a presença ostensiva do tráfico de drogas.

"Otário, perdeu a casa!", eis a frase provocativa que fora repetida sistematicamente entre o círculo de amigos de Marcelo. A questáo patrimonial passou a ser um motivo de aproximação para fracassadas tentativas de conciliação de bens entre Marcelo e Michele. Marcelo via as negociaçóes como vontade de conciliação do casal. Em uma das tentativas de negociação, Marcelo aproveitou um encontro marcado em local público e a violentou. Nessa segunda agressão, Michele perdeu os dentes, teve o braço quebrado e um hematoma no cérebro. No hospital particular, Michele mentiu dizendo para o médico que se envolveu em uma briga com outra mulher. Ao se recuperar, recorreu à boca de fumo num momento em que acreditava já saber como proceder para que tal negociação fosse bem-sucedida, e sem violência:

Michele: O segredo foi chegar na "humildade" [...] quer dizer, preferi chegar perguntando se poderia dar parte na Delegacia de Mulher pra mostrar que eu considerava a opinião deles [do tráfico] na favela. O importante era eu jogar com eles dizendo como resolver esse caso na justiça, que tenho direito. Falando que eu tenho esse direito é uma forma de não pedir ou ficar devendo favor pra eles, tipo implorar "ah, por favor, resolva o meu caso!”. Não! Mostrei que era meu direito, mas mesmo assim cheguei na "humildade" já que eu não tenho "vacilação" na favela. Assim, eu ganhei um ponto.

Em nossa conversa, Michele tentou relembrar a fala de cada um no "desenrolo":22
Michele: A questão é que o meu marido não quer a separação. Já nos envolvemos em diversas situações de violência. Ele me agrediu, fui parar no hospital. Os médicos queriam saber o que aconteceu. Por isso, preferi ir ao hospital particular. Mas a minha família acha certo que eu recorra à Lei Maria da Penha, um direito que eu tenho. Tá na mídia. Mesmo assim eu considerei a situação da favela, de vocês aqui. Não sei se a polícia pode bater aqui e tal. Queria saber se posso ir à Delegacia de Mulheres.

Traficante: Realmente tem o problema da polícia entrar. No hospital público já tem polícia pra fazer o boletim de ocorrência em caso de violência contra a mulher. Por causa da Lei Maria da Penha se o médico identificar já faz a ocorrência. Problema que acontece na favela tem que ser resolvido dentro da favela! Gostei da sua consideração por nós aqui! Achei legal da sua parte, mas... teve traição no caso?

Michele: Não, nada de traição! Sou "tranquila". Pode procurar saber. Só quero paz.

Traficante: Então, acabou o amor? Qual o seu direito nessa Lei [Lei Maria da Penha]?

Michele: Não sei. Quero que ele saia de casa porque ele tem outros imóveis e eu não tenho pra onde ir. Depois eu posso pagar a parte dele, é só ver a minha condição.

Traficante: Ele tá errado, se fosse pela Lei você ficaria com metade dos bens dele! Por direito mesmo. Pensando bem, nem precisa pagar a parte dele, se é pra ficar na paz, tudo bem. Sabemos que ele é um cara trabalhador, não há porque fazer nada com ele. Não vou chegar nele direto para ele não dizer que você trouxe a situação de vocês pra "boca". Vou desenrolar isso conversando com alguém ligado a ele que conheço aqui na favela. Mas sabe que depois você não pode mais voltar com ele, certo?

Michele: Sei, pode ficar tranquilo! Só vim aqui porque não teve mais jeito, foi no último caso mesmo. Não queria que fizesse nada com ele, não desejo mal.

Traficante: Fica tranquila, os moradores só vêm na "boca" quando não tem mais jeito, já tentou de tudo. 
"Partiu para a baixaria? Eu quero a legalidade!", disse Marcelo. Indignado, ele foi chamado à "boca", mas não compareceu. Mesmo parecendo uma afronta, Marcelo foi considerado pelo bandido. Este disse que ia deixar passar alegando que ele é homem, e homem de verdade não consegue entender como outro homem - bandido - pode decidir sua vida. O potencial de violência nesse encontro é inegável, no caso, o bandido não queria quebrar a honra masculina, mas, ao mesmo tempo, não aceitaria uma reação agressiva de outro homem. O recado da "boca" foi dado: "Fiquem na paz, sem violência. Tentem resolver, não quero agressóes!" Assim, nesse caso, a honra masculina foi preservada no "desenrolo" como estratégia de frear açōes violentas.

As narrativas sobre os "desenrolos", em geral, recuperam tais eventos a partir da capacidade de contornamento. Um conhecido que também "foi para desenrolo" descreveu sua performance da seguinte forma:

Eu estava muito tenso, mas não me abati, eu nem me reconheci na hora, não sabia que poderia agir daquela maneira, de poder me afirmar assim, na frente dos caras só de fuzil. No início o cara tava querendo me intimidar, mas ele foi mudando o tom, disse que não tinha nada contra ninguém e tal... foi tudo desenrolado. Eu não entrei em contradição, ele não teve como me cercar nas palavras [morador da Maré, 2011].

O caso deixa entrever o nexo e o manejo complexo entre autoridade - a mulher fiel, que não "trai" o marido - e autonomia - da moradora "humilde" e portadora de direitos. Através desse caso, procurei mostrar como a Lei Maria da Penha foi usada em sua ênfase na abstração de cidadania das mulheres em contexto fortemente estruturado pelo sexismo. Em sua defesa, a vítima valoriza a conduta ética ao longo do processo em que a pessoa vai se diferenciar do crime na humildade. Ter disciplina e humildade, repertórios do crime, significa manter-se em uma perspectiva equalizadora mesmo no contexto em que bandido e morador são categorias distintas e opostas. No cotidiano de incerteza sobre a continuidade das rotinas (Machado da Silva, 2008), essas categorias, ao fazerem conexóes comu- nicativas, atuam como dispositivos de expansão do crime em torno da disputa legítima sobre o sentido prático da "vida" como experiência dicotômica entre a guerra e a paz.

\section{Conclusão}

Integrando a produção do comum na pesquisa (Pina-Cabral, 2003), pontuo que o lugar de fala $\mathrm{da}$ pesquisadora "nativa" precisa ser refletido em relação à intersubjetividade etnográfica. Arrisco-me a dizer que as experiências partilhadas implicam não apenas o lidar com os imponderáveis da pesquisa, mas sobretudo traz uma gama maior de indicialidades (em locuçóes do tipo "como você sabe, Carla") demarcadoras da "experiência vivida". Estas indexaçóes é um meio privilegiado para compreender o "horizonte narrativo" e sua modulação política propriamente dita. Similar às modulaçóes das narrativas musicais ligadas ao funk, como tenho estudado, o território emerge como "quadro de vida" - tal como formulou o geógrafo Milton Santos (1994) -, assinalando as limitaçōes de fala, mas também a sua potência teórica. Conquanto não se pode homogeneizar as maneiras diversas de se vivenciar $\mathrm{e}$ narrar o cotidiano na favela, as experiências estáo atravessadas pela constataçáo de que o que acontece aqui não é o mesmo que acontece "lá fora", ou se acontece não é igual. As experiências de subalternidade na cidade, concretizadas pela modalidade de presença desigual e violenta do Estado, conformam o ponto de aproximação, a despeito da diversidade da favela, inscrita na pesquisa favelada.

A partir do ponto de observação privilegiado deste artigo, é possível desnaturalizar a pressuposição de que as favelas, submetidas ao controle estrito da violência do tráfico de drogas, são, ao mesmo tempo, lócus e causa da "violência urbana". Na etnografia analisada, o que se vê é uma ordem específica, mas nunca desordem, tampouco caracteriza o lugar do Estado ausente. Ao contrário, governos locais, de Jorge Negáo a Andrezinho Moral, e governos externos, entre facções rivais, incursões policiais e políticas de segurança pública, são práticas relacionadas e partes integrantes de um mesmo ordenamento. Desse conjunto de relaçóes é possí- 
vel compreender o descaso sobre as fronteiras relevantes aos moradores em torno da implementação do 22․ Batalhão da PM na Maré. Nessa lógica, o confronto entre facções rivais e a atuação dos Caveiróes complementam-se, sustentando uma complexa rede ilegal de "mercadorias políticas" (Misse, 2010) e econômicas (Feltran, 2014). Esses distintos regimes coproduzem a ordem da favela estudada, repercutindo no restante da cidade.

\section{Notas}

1 Evento organizado pelo Instituto de Estudos da Religião (Iser), Luta pela Paz, Redes da Maré e Observatório de Favelas - organizaçóes da sociedade civil dedicadas aos direitos humanos.

2 A Nova Holanda é uma das dezessete favelas do Complexo da Maré, localizada na Zona Norte entre as duas principais avenidas que atravessam o Rio de Janeiro, a Avenida Brasil e a Linha Vermelha. No final de março de 2014, a Maré foi ocupada por 2.500 agentes do Exército e da Marinha que, segundo o discurso oficial, serviria para "preparar" a chegada da 390 Unidade de Polícia Pacificados (UPP) prevista em julho de 2015.

3 A produção de "políticas locais" realizadas nas interaçóes entre polícia, crime e cadeia foram analisadas por Silva (2014) em uma quebrada de São Paulo.

4 Segundo Luiz Antonio Machado da Silva (2015) a polarização entre as linguagens da "violência urbana" e dos direitos tem sua origem nos anos de 1980 no governo Brizola, marcando as reivindicaçóes de preservação da ordem cujo debate desacredita e criminaliza as experiências dos moradores de favelas.

5 Conforme destaca Gabriel Feltran (2013), a humildade é uma categoria associada à matriz cristã, integrando as noçóes de justiça presentes na literatura sobre as moralidades populares, e que no contexto de expansão do PCC, nos presídios e nas periferias de São Paulo articula o ideal de igualdade. Sobre as relaçôes entre igualdade e humildade na construção do ideal de "comando sem comando" no PCC, ver Adalton Marques (2011).

6 "Desenrolo" é uma expressão comum usada para ressaltar a seriedade de uma conversa. Nela, alguém precisa criar argumentos para fins de convencimento ou esclarecimento acerca de um assunto. Em recente transfiguração semântica, o termo passa a se referir exclusivamente às conversas entre traficantes e moradores (Mattos, 2014 a) e entre estes últimos (Grillo, 2013).
7 Embora usada como estratégia de escrita, considero a cisão entre as narrativas de moradora e de pesquisadora problemática do ponto de vista político-epistemológico. Retomarei este ponto na conclusão deste artigo.

8 O homem mau figura o bandido justiceiro e ordenador da paz armada de favelas e morros cariocas. Este personagem aparece nas cançóes de Roberto Carlos, Jorge Ben e da dupla sertaneja de Goiânia, Léo Canhoto e Robertinho (ver https:/www.youtube.com/ watch?v=zJXeVdiizUA, consultado em 21/10/2014).

9 Sobre os sequestros de traficantes realizados por policiais nas periferias de São Paulo, ver Hirata (2010).

10 "Dar derrame na boca" é quando alguém é considerado incapaz de arcar com as dívidas adquiridas em compras de drogas.

11 Rogério Lemgruber foi considerado a principal referência na organização do Comando Vermelho dentro do presídio da Ilha Grande, entre aos anos de 1960 e 1970.

12 A expressão "envolvido na boca" equivale dizer que uma pessoa integra o grupo de traficantes da localidade, podendo ser ladrão ou alguém que se associa às atividades de venda de drogas.

13 "Invasão" ou "baque" são termos utilizados para se referir às tentativas da facção rival em atravessar as fronteiras territoriais das favelas que dividem os "comandos" - limites chamados de "divisas".

14 Em minhas lembranças, o Comando Vermelho iniciou o controle do tráfico na Nova Holanda em 1994. A rivalidade com a facção que controlava os pontos de drogas da favela vizinha, Baixa do Sapateiro, começou em 1997. As "invasóes" foram iniciadas em 5 de fevereiro de 1999.

15 Nesse caso específico, chama-se de "missóes" as atividades de apoio ou de defesa às “invasóes”. Executar um plano de resgate, atravessar armamento para reforço na favela "do alemão" e roubar carros para tais fins são exemplos de "missóes" associadas à guerra.

16 Disponível em http://www1.folha.uol.com.br/cotidiano/ 2008/06/413016-oficial-planejou-entregar-jovens-a-traficantes-rivais-diz-policia-do-rio.shtml, consultado em 7/4/2016

17 Karina Biondi (2007) e Adalton Marques (2011), ao discorrerem sobre a organização do PCC nos presídios e nas periferias de São Paulo, discutem o princípio da "igualdade" e a sua adição ao lema apropriado do Comando Vermelho "Paz, Justiça e Liberdade". Segundo seus interlocutores, este princípio é emblemático da "paz entre os ladrões" e marco fundante do processo de pacificação criminal nas cadeias e periferias de São Paulo. 
18 Em seu livro A república dos meninos: juventude, tráfico e virtude, Diogo Lyra explora os princípios de coesão social entre jovens traficantes da Baixada Fluminense no Rio de Janeiro.

19 Destaco, desde logo, que minha interpretação é fortemente marcada por meu envolvimento em um "desenrolo", o que me permitiu compreender parte do mecanismo de justiça em questáo para interpretar o caso que agora apresento (Mattos, 2014a).

20 Nesta etnografia criei personagens e situaçóes inspiradas em três casos de litígio e agressão que observei na favela Nova Holanda. A estratégia ficcionalizante tem por objetivo preservar a identidade das pessoas envolvidas nesses casos.

21 A "mulher fiel" é aquela assumida publicamente pelo homem na relação conjugal, tendo a sua identidade marcada pela fidelidade como atributo essencial que caracteriza a mulher de verdade para casar e constituir família.

22 À medida que Michele ia narrando o "desenrolo", rascunhei a conversa. A versão ora apresentada teve o texto finalizado por Michele.

\section{BIBLIOGRAFIA}

BARBOSA, Antônio Rafael. (2005), Prender e dar fuga: biopolitica, sistema penitenciário e tráfico de drogas no Rio de Janeiro. Tese de doutorado, Programa de Pós-Graduação em Antropologia Social, Museu Nacional, Universidade Federal do Rio de Janeiro (datilo.).

BIONDI, Karina. (2007), Junto e misturado: uma etnografia do PCC. São Paulo, Terceiro Nome.

FELTRAN, Gabriel de Santis. (2011), Fronteiras de tensão: política e violência na periferia de São Paulo. São Paulo, Editora da Unesp/CEM.

(2013), "Sobre anjos e irmãos: cinquenta anos de expressão política do 'crime' numa tradição musical das periferias”. Revista do Instituto de Estudos Brasileiros, 56: 43-72. Disponível em http://dx.doi.org/10.11606/ issn.2316-901X.v0i56p43-72.

. (2014), "O valor dos pobres: a aposta no dinheiro como mediação para o conflito social contemporâneo". Caderno CRH, 27 (72): 495-512.

GOFFMAN, Erving. (2012), Os quadros da experiência social: uma perspectiva de análise. Petrópolis, Vozes.
GRILLO, Carolina Christoph. (2013), Coisas da vida do crime: tráfico e roubos em favelas cariocas. Tese de doutorado, Instituto de Filosofia e Ciências Sociais, Universidade Federal do Rio de Janeiro (datilo.).

HIRATA, Daniel. (2010), Sobreviver na adversidade: entre o mercado e a vida. Tese de doutorado, Faculdade de Filosofia, Letras e Ciências Humanas, Universidade de São Paulo.

LEITE, Márcia P. (2008), "Violência, risco e sociabilidade nas margens da cidade: percepções e formas de ação de moradores de favelas cariocas", in L. A. Machado da Silva (org.), Vida sob cerco: violência e rotina nas favelas do Rio de Janeiro. Rio de Janeiro, Nova Fronteira.

LOPES, Paulo Victor Leite. (2011), Sexualidade e construção de si em uma favela carioca: pertencimentos, identidades e movimentos. Dissertação de mestrado, Museu Nacional, Universidade Federal do Rio de Janeiro, Rio de Janeiro (datilo.).

LYRA, Diogo. (2013), A república dos meninos: juventude, tráfico e virtude. Rio de Janeiro, Mauad.

MACHADO DA SILVA, Luiz Antonio. (2008), "Violência urbana, sociabilidade violenta e agenda pública”, in L. A. Machado da Silva (org.), Vida sob cerco: violência e rotina nas favelas do Rio de Janeiro. Rio de Janeiro, Nova Fronteira.

. (2015), "A experiência das UPPs: uma tomada de posição". Dilemas - Revista de Estudos de Conflitos e Controle Social, 8 (1): 7-24.

MACHADO DA SILVA, Luiz Antonio; LEITE, L \& FRIDMAN, L. (2005), "Matar, morrer, civilizar: o problema da segurança pública”. Relatório do projeto Ibase/Action Aind-Brasil/Fundação Ford, dez. Disponível em www.ibase.br.

MARQUES, Adalton. (2011), “'Liderança', 'proceder' e 'igualdade': uma etnografia das relaçóes políticas no Primeiro Comando da Capital”. Etnográfica, 14 (2): 311-335.

MATTOS, Carla dos Santos. (2012), "Da valentia à neurose: criminalização das galeras funk, 'paz' e (auto)regulação das condutas nas favelas". Dilemas - Revista de Estudos de Conflitos e Controle Social, 5 (4): 653-680. 
. (2014a), Viver nas margens: gênero, crime e regulaçáo de conflitos. Tese de doutorado, Programa de Pós-Graduação em Ciências Sociais, Universidade do Estado do Rio de Janeiro.

. (2014b), "Parado na esquina": performances masculinas e identificaçóes entre 'bondes' juvenis na Nova Holanda, Maré, RJ”. Dilemas - Revista de Estudos de Conflitos e Controle Social, 7 (4): 643-663.

MISSE, Michel. (2003), "O movimento: a constituição e reprodução das redes do mercado informal ilegal de drogas a varejo no Rio de Janeiro e seus efeitos de violência”, in Marcos Baptista, Marcelo S. Cruz e Regina Matias (orgs.), Drogas e pós-modernidade, Rio de Janeiro, Eduerj. . (2010), "Crime, sujeito e sujeição criminal: aspectos de uma contribuição analítica sobre a categoria 'bandido' ”. Lua Nova, 79: 15-38.

PINA-CABRAL, João de. (2003), "Semelhança e verossimilhança: horizontes da narrativa etnográfica”. Mana, 9 (1): 109-122.

SANTOS, Milton. (1994), Território globalização e fragmentação. São Paulo, Hucitec, 1994.

SILVA, José Douglas. (2014), Politicas locais e politicas estatais referentes aos homicidios em Luzia, São Paulo. Dissertação de mestrado, Universidade Federal de São Carlos (datilo.).

SILVA, Eliana Souza. (2010), O contexto das práticas policiais nas favelas da Maré: a busca de novos caminhos a partir de seus protagonistas. Tese de doutorado, Departamento de Serviço Social da Pontifícia Universidade Católica do Rio de Janeiro (datilo.).

VIEGAS, Susana de Matos \& MAPRIL, José. (2012), "Mutualidade e conhecimento etnográfico". Etnográfica, 16 (3): 513-524.

ZALUAR, Alba. (1985), A máquina e a revolta. São Paulo, Brasiliense. 


\section{UMA ETNOGRAFIA DA EXPANSÁO DO MUNDO DO CRIME NO RIO DE JANEIRO}

\section{Carla dos Santos Mattos}

Palavras-chave: Conflitos; Complexo da Maré; Sociabilidade urbana; Violência criminal; Violência policial

Comparando três décadas, este artigo descreve o contexto histórico da emergência da faç̧ão e de sua expansão na Favela Nova Holanda, em Maré, no Rio de Janeiro. Através das categorias "neurose" e "humildade”, apresenta como o quadro de referência "facção" dá inteligibilidade à vida como guerra ou paz, respectivamente. Sobre tal processo, argumenta que as operaçóes policiais, as incursões dos "Caveirões" carros blindados da Polícia Militar - e as disputas violentas entre facções vão se consolidando como dispositivos responsáveis por expandir o "mundo do crime". No que diz respeito às práticas criminais, as mediações chamadas de "desenrolos" passam a configurar um espaço de interação no qual a força (armada) e a argumentação se sobrepõem e se fundem com frequência no âmbito dos conflitos.

\section{AN ETHNOGRAPHY OF THE EXPANSION OF THE CRIMINAL WORLD IN RIO DE JANEIRO}

\section{Carla dos Santos Mattos}

Keywords: Conflicts; Complexo da Maré; Urban sociability; Criminal violence; Police violence

Through a comparison involving three decades, this article describes the historical context in which the faction emerges and expands itself in the Favela Nova Holanda, in the Complexo da Maré, Rio de Janeiro. By means of the categories of "neurosis" and "humility", it presents the faction's reference framework which gives intelligibility to their members' life as war or peace, respectively. About such process, it argues that police operations, police raids with the "caveirões" - armored cars used by the military police -, and violent disputes between factions are becoming consolidated as the devices responsible for the expansion of the "world of crime". In what comes to the criminal practices, the mediations known as desenrolos establish an interactive space in which (armed) force and argument frequently overlap and merge one another in the spectrum of the conflicts.

\section{UNE ETHNOGRAPHIE DE L'EXPANSION DU MONDE DU CRIME À RIO DE JANEIRO}

\section{Carla dos Santos Mattos}

Mots-clés: Conflits; Complexo da Maré; Sociabilité urbaine; Violence criminelle; Violence policière.

Cet article décrit, par la comparaison au long de trois décennies, le contexte historique de l'émergence de la faction et son expansion dans la Favela Nova Holanda, dans le quartier de la Maré à Rio de Janeiro. Grâce aux catégories "névrose" et "humilité", l'article présente, en tant que cadre de référence, la "faction" et rend intelligible la vie en tant que guerre ou paix, respectivement. À propos de ce processus, nous affirmons que les opérations de police, les incursions des voitures blindées de la police militaire connues sous le nom de "Caveirões" et les conflits violents entre factions se consolident comme des dispositifs responsables de l'expansion du "monde du crime". En ce qui concerne les pratiques criminelles, les médiations dénommées "desenrolos" commencent à mettre en place une interaction dans laquelle la force (armée) et l'argumentation se superposent et se fondent fréquemment dans le cadre des conflits. 